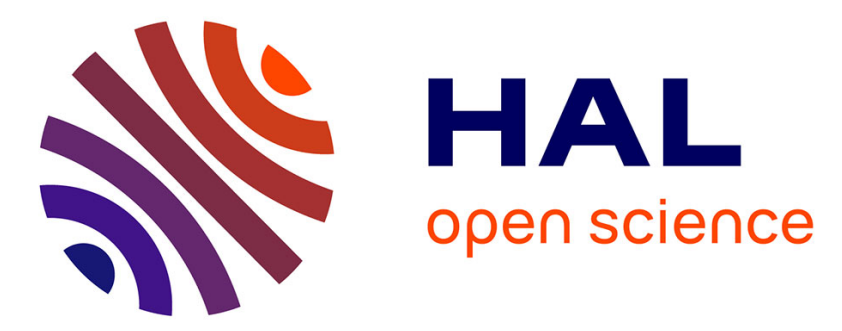

\title{
Oxidation of a PAH polluted soil using modified Fenton reaction in unsaturated condition affects biological and physico-chemical properties
}

Fabien Laurent, Aurélie Cébron, Christophe Schwartz, Corinne Leyval

\section{- To cite this version:}

Fabien Laurent, Aurélie Cébron, Christophe Schwartz, Corinne Leyval. Oxidation of a PAH polluted soil using modified Fenton reaction in unsaturated condition affects biological and physico-chemical properties. Chemosphere, 2012, 86, pp.659-664. 10.1016/j.chemosphere.2011.11.018 . hal-01486347

\section{HAL Id: hal-01486347 \\ https://hal.science/hal-01486347}

Submitted on 27 Feb 2019

HAL is a multi-disciplinary open access archive for the deposit and dissemination of scientific research documents, whether they are published or not. The documents may come from teaching and research institutions in France or abroad, or from public or private research centers.
L'archive ouverte pluridisciplinaire HAL, est destinée au dépôt et à la diffusion de documents scientifiques de niveau recherche, publiés ou non, émanant des établissements d'enseignement et de recherche français ou étrangers, des laboratoires publics ou privés. 
1 Oxidation of a PAH polluted soil using modified Fenton reaction in unsaturated

2 condition affects biological and physico-chemical properties

3

4 Laurent $\mathrm{F}^{1,2}$, Cébron $\mathrm{A}^{1}$, Schwartz $\mathrm{C}^{2}$, Leyval $\mathrm{C}^{1^{*}}$

5

$6 \quad{ }^{1}$ LIMOS UMR7137 Nancy Université CNRS, BP 70239, F-54506 Vandœuvre-lès-Nancy

7 cedex, France

$8{ }^{2}$ LSE UMR 1120 Nancy Université INRA, BP 172, F-54505 Vandœuvre-lès-Nancy cedex,

9 France

10

11 *Corresponding author: Corinne Leyval, LIMOS UMR7137 Nancy Université CNRS, Faculté

12 des Sciences et Technologies, BP 70239, 54506 Vandoeuvre-les-Nancy Cedex, France, tel: 33

13 (0)3 836842 82, fax: 33 (0)3 836842 84, e-mail: corinne.leyval@,limos.uhp-nancy.fr

14

15 


\section{Abstract}

17 A batch experiment was conducted to assess the impact of chemical oxidation using modified Fenton reaction on PAH content and on physico-chemical and biological parameters of an industrial PAH contaminated soil in unsaturated condition. Two levels of oxidant $\left(\mathrm{H}_{2} \mathrm{O}_{2}, 6\right.$ and $65 \mathrm{~g} \mathrm{~kg}^{-1}$ ) and $\mathrm{FeSO}_{4}$ were applied. Agronomic parameters, bacterial and fungal density, microbial activity, seed germination and ryegrass growth were assessed. Partial removal of PAHs (14 and 22\%) was obtained with the addition of oxidant. The impact of chemical oxidation on $\mathrm{PAH}$ removal and soil physico-chemical and biological parameters differed depending on the level of reagent. The treatment with the highest concentration of oxidant decreased soil $\mathrm{pH}$, cation exchange capacity and extractable phosphorus content. Bacterial, fungal, and PAH degrading bacteria densities were also lower in oxidized soil. However a rebound of microbial populations and an increased microbial activity in oxidized soil were measured after 5 weeks of incubation. Plant growth on soil treated by the highest level of oxidant was negatively affected.

Keywords: Fenton, oxidation, PAH, soil, fertility, biological activity

\section{Introduction}

The presence of pollutants in soils can affect soil functions (e.g. filter and exchange, support

37 for plant growth and biodiversity) (Smith et al., 2006; Maxim and Spangenberg, 2009).

38 Although remediation treatments reduce or eliminate pollutant concentration, their potential

39 effect on soil physical, chemical and biological properties, and soil functions is rarely 40 considered. Polycyclic aromatic hydrocarbons (PAHs) are widespread contaminants in soil. 
Their effects on human health and their carcinogenic potential is largely studied (Bispo et al., 1999; Joe et al., 2004; White and Claxton, 2004). Different remediation technologies were developed in the last decades to remove PAHs from contaminated soils (Wang et al., 1990; Cajthaml et al., 2002; Gan et al., 2009). In situ chemical oxidation (ISCO) is a technology generally used to remediate organic contaminants in groundwater and saturated soil (Rivas, 2006; Huling and Pivetz, 2006). This remediation technique based on the injection of different oxidant reagents does not require soil excavation and represents an alternative to conventional treatment (e.g. thermal desorption, venting). Fenton reagents (hydrogen peroxide and iron) are among the most commonly used and studied oxidizing agents (Rivas, 2006) for pollutants such as petroleum hydrocarbons, BTEX, chlorinated ethenes and PAHs (Huling and Pivetz, 2006). In Fenton reaction, Fe (II) catalyzes the decomposition of hydrogen peroxide to generate hydroxyl radicals $\left(\mathrm{OH}^{*}\right)$ which are strong and non specific oxidants. However, some authors showed that $\mathrm{OH}^{\cdot}$ radicals preferentially attack the aromatic compounds (Westerhoff et al., 1999; Mikutta et al., 2005) and can also react with sorbed and aqueous PAHs. Fenton oxidation generally includes acid addition since a low $\mathrm{pH}(2-3)$ is required for optimum reaction, but modified Fenton reaction at near neutral $\mathrm{pH}$ using ferric ions and chelating agents was also performed (Nam et al., 2001).

Fenton reaction was mainly studied in saturated conditions (Jonnson et al., 2006; Sirguey et al., 2008; Sun and Yan, 2008; Valderrama et al., 2009) with large liquid/solid ratios. Further, the amounts of oxidant used in many studies (Nam et al., 2001; Palmroth et al., 2006a; Valderrama et al., 2009) were very high for field treatment. Chemical oxidation in unsaturated conditions was also applied, although fewer studies were reported (Palmroth et al. 2006a, Huling and Pivetz, 2006). The addition of chemical oxidants could impact other soil characteristics than organic pollutant concentration and for surface soils this could lead to a global loss of fertility. Chemical oxidation of PAHs was shown to induce a decrease of 
organic carbon, total nitrogen and phosphorus contents in soils (Leifeld and Kögel-Knabner, 2001; Mikutta et al., 2005; Sirguey et al., 2008). Microorganism populations were negatively affected following ISCO but the impact seemed to be temporary with a rebound of cell numbers after a few weeks (Sahl and Munakata-Marr, 2006). After oxidation treatment, PAH biodegradation was enhanced, suggesting the possible combination of both chemical oxidation and biodegradation of organic pollutants (Lee and Hosomi, 2001; Nam et al., 2001; Palmroth et al., 2006a; 2006b; Valderrama et al., 2009)

The present study was conducted to assess the impact of chemical oxidation to surface soil using modified Fenton reaction on PAH removal and on soil physico-chemical and biological parameters. Since surface soils are mostly unsaturated, we performed the oxidation in unsaturated condition. An industrial PAH contaminated soil was treated with a volume of reagents calculated to keep the soil at water holding capacity. We used a modified Fenton reaction without acid addition to the soil to avoid a strong $\mathrm{pH}$ decrease that may drastically affect biological activity. Two concentrations of reagents were tested. Analyses of PAH concentration, soil characteristics $(\mathrm{pH}$, cation exchange capacity, organic carbon, nitrogen, phosphorus), microbial density and activity and seed germination and plant growth using ryegrass (Lolium perenne) were performed with oxidized and control soil.

\section{Materials and methods}

\subsection{Soil sampling and analysis}

An industrial soil sample was collected from a former coking plant site (Neuves-Maisons, France) (Biache et al., 2008; Monsérié et al., 2009). The soil is a sandy loamy soil (11.9\% clay, $21.5 \%$ silt and $66.6 \%$ sand). The soil presents a high content of organic carbon $\left(50 \mathrm{~g} \mathrm{~kg}^{-1}\right)$, a neutral $\mathrm{pH}(7.3)$ and the contamination by the 16 US-EPA priority PAHs reaches 
$911200 \mathrm{mg} \mathrm{kg}^{-1}$. Large amount of soil was excavated and homogenized by quartering. Sub92 samples were sieved at $2 \mathrm{~mm}$ and air dried at $25^{\circ} \mathrm{C}$. Soil analyses were performed by INRA 93 laboratory (Arras, France) according to international standard methods: water holding capacity (WHC) (ISO 11464), pH, total organic carbon (ISO 10694), total nitrogen (ISO 13878), extractable phosphorus (ISO 11263), cation exchange capacity (CEC, NF X 31-130).

\subsection{Oxidation experiment}

The modified Fenton reaction was performed with two levels of reagents corresponding to $6 \mathrm{~g}$

$\mathrm{kg}^{-1}$ (low, L) and $65 \mathrm{~g} \mathrm{~kg}^{-1}$ (high, $\mathrm{H}$ ) of $\mathrm{H}_{2} \mathrm{O}_{2}$. Three glass containers were filled with $1500 \mathrm{~g}$ of $2 \mathrm{~mm}$ sieved soil at $5 \%$ humidity. In two of them, the soil sample was mixed with 7 (L) or $82(\mathrm{H}) \mathrm{g}$ of solid ferrous sulfate $\left(\mathrm{FeSO}_{4}, 7 \mathrm{H}_{2} \mathrm{O}, 99.5 \%\right.$ purity) to catalyse the decomposition of $\mathrm{H}_{2} \mathrm{O}_{2}$ without increasing the volume of solution added. Then, $450 \mathrm{~mL}$ of a solution of $\mathrm{H}_{2} \mathrm{O}_{2}$ at either $0.54(\mathrm{~L})$ or $6.3 \mathrm{M}(\mathrm{H})$ were added gradually to reach water holding capacity. The third one was a control with addition of $450 \mathrm{~mL}$ of water and no reagent addition. After $48 \mathrm{~h}$, the soil sample in each container was homogenized and sub-sampled for further analysis. The soil was then air dried and sieved to $2 \mathrm{~mm}$ again. For microbial analysis, sub-samples were

107 directly used for quantification of culturable heterotroph bacteria and incubation. For DNA 108 extraction sub-samples were stored at $-20^{\circ} \mathrm{C}$.

\subsection{Measurement of microbial activity (carbon mineralization) in soil after oxidation}

111 Fenton oxidized and control soil samples $(20 \mathrm{~g})$, with five replicates each, were incubated at

$112100 \%$ WHC in $150 \mathrm{~mL}$ serum bottles with a Teflon septum for 5 weeks at $24^{\circ} \mathrm{C}$ to measure

113 microbial activity by $\mathrm{CO}_{2}$ production. To avoid anaerobic conditions during incubation,

114 bottles were aired out every week. Carbon dioxide $\left(\mathrm{CO}_{2}\right)$ release was measured every day by 
115 infrared spectrophotometer (Binos, absorption at $2325.6 \mathrm{~cm}^{-1}$ ) (Quantin et al., 2005). After 5

116 weeks, five replicates were taken for microbial and PAH analysis as described hereafter. An

117 abiotic control of each modality (autoclaved twice at an interval of $48 \mathrm{~h}$ ) was performed for a

118 week in order to evaluate the abiotic release of $\mathrm{CO}_{2}$.

\subsection{MPN counts of heterotroph microorganisms}

121 Soil (1 g fresh) was suspended in $10 \mathrm{~mL}$ sterile ultra-pure water with $6 \mathrm{~g}$ sterile glass-beads and soil suspension was shaken during $1 \mathrm{~h}$. Serial dilution of soil suspension $\left(10^{-2}\right.$ to $\left.10^{-7}\right)$ was prepared in $\mathrm{NaCl}(0.85 \%)$. The most-probable-number (MPN) was counted in 96-well

124 microplates. A volume $(25 \mu \mathrm{L})$ of dilution was added with $200 \mu \mathrm{L}$ nutrient broth liquid 125 medium $\left(1 \mathrm{~g} \mathrm{~L}^{-1}\right)$ in each well with 40 replicates by dilution. Microplates were incubated for $12648 \mathrm{~h}$ at $28^{\circ} \mathrm{C}$ then absorbance was measured at $620 \mathrm{~nm}$ and MPN counts calculated by a computer program using McCrady table (Binet et al., 2000).

\subsection{Quantification of bacteria, fungi and PAH-degrading bacteria}

130 DNA extractions were performed independently for each biological replicate. DNA was

131 extracted using the FastDNA ${ }^{\odot}$ Spin kit for soil according to manufacturers recommendations

132 (MP Biomedicals) from $1 \mathrm{~g}$ of soil. Bacteria, fungi and PAH-degrading bacteria were 133 quantified by targeting $16 \mathrm{~S}$ rDNA, $18 \mathrm{~S}$ rDNA and $\mathrm{PAH}_{-\mathrm{RHD}}$ genes using real-time PCR

134 quantification of gene copy number, with the primer sets 968F/1401R (Felske et al., 1998), 135 FF390R/Fung5F (Lueders et al., 2004), PAH-RHD ${ }_{\alpha}$ GN F/R and PAH-RHD ${ }_{\alpha}$ GP F/R (Cébron 136 et al., 2008), respectively. Real-Time PCR experiments were conducted in triplicate with an 137 iCycler iQ (Bio-Rad), associated with iCycler Optical System Interface software (version 138 2.3). The final volume used $(20 \mu \mathrm{L})$ contained $10 \mu \mathrm{L}$ of iQ SYBR GREEN SuperMix 139 (Biorad), $0.4 \mu \mathrm{M}$ each primer, $0.06 \%$ bovine serum albumine (BSA), $0.2 \mu \mathrm{L}$ DMSO, $0.08 \mu \mathrm{L}$ 
140 T4gp32 (MP Biomedicals) and $1 \mu \mathrm{L}$ of DNA as described in Cébron et al. (2008).

141 Quantitative calibrations of Real-Time PCR assays were performed with 10 times dilution

142 series (from $10^{8}$ to $10^{3}$ target gene copies $\mu \mathrm{L}^{-1}$ ) of standard linearized plasmids (pCR2.1

143 vector from Invitrogen) with target gene fragment inserted (Cébron et al., 2008).

\subsection{Germination and plant growth test}

146 Fenton oxidized and control soil samples $(100 \mathrm{~g})$ with five replicates were placed in $200 \mathrm{~mL}$

147 pots. Soil was watered with deionised water to $70 \%$ WHC and soil moisture was daily

148 adjusted. Twenty seeds were sown on each pot, thinned to 5 plants after germination. The pots

149 were placed in a growth chamber at $24^{\circ} \mathrm{C} / 20^{\circ} \mathrm{C}, 16 \mathrm{~h}$ day light, $250 \mu \mathrm{mol} \mathrm{m} \mathrm{m}^{-2}$ intensity.

150 The germination rate was recorded every day and conducted over a period of 2 weeks. After 4

151 weeks, plants were harvested, and roots gently rinsed in water. Shoot and root dry weights

152 were measured after drying at $105^{\circ} \mathrm{C}$ for $24 \mathrm{~h}$.

\subsection{PAH analysis}

155 PAHs were extracted from soil samples in triplicates using ASE 200 (Accelerated Solvent

156 Extraction Dionex). Anhydrous sodium sulfate $(1 \mathrm{~g})$ and $1 \mathrm{~g}$ of Florisil ${ }^{\circledR}$ was added to each

157 sample $(1 \mathrm{~g})$ in the extraction cell to purify the extract. The extraction solvent was composed

158 of $50 \%$ acetone and $50 \%$ methylene chloride and extraction was run at $100^{\circ} \mathrm{C}$ and 130 bars

159 for 5 min (Ouvrard et al., 2011). After evaporation of most of the solvent, samples were

160 diluted in $5 \mathrm{~mL}$ of acetonitrile and evaporated to obtain exclusive acetonitrile extracts.

161 Analysis of 16 US-EPA priority PAHs concentrations was performed by high-performance

162 liquid chromatography (Varian) (Monsérié et al., 2009). Results were reported for dry soil for

163 comparison between treatments.

164 
166 Statistical analyses were performed using XLSTAT@ Software. Comparisons were made by

167 ANOVA after verification of applicability conditions. A multiple post hoc comparison

168 (Tukey) test was applied to determine the difference per pair. Gene quantification data were

$169 \log$ transformed for statistical comparisons. To test time effect of bacteria recolonization a

170 Student t-test was applied. For seed germination a Fisher test was applied to calculate LSD

171 (least significant difference).

172

\section{3. Results}

3.1. Effect of Fenton oxidation on soil PAH concentration and physico-chemical characteristics

177 Total PAH concentration was significantly lower in Fenton oxidized than in control soil with $22 \%$ and $14 \%$ decrease with $\mathrm{H}$ and $\mathrm{L}$ oxidant concentration, respectively (Table 1 ). The same result was found for the individual PAHs except for the three low molecular weight PAHs

180 naphthalene, acenaphtylene and acenapthene where the concentration decrease was not

181 significant (Table 1). No clear difference was observed for the degradation rate between the 3 182 (18 to $36 \%$ decrease with $\mathrm{H}$ oxidant concentration), 4 (20.3 to $24.3 \%$ ), 5 (16 to $22.1 \%$ ) and 6

183 (24.3 to $24.6 \%$ ) ring PAHs. No further significant PAH concentration decrease occurred 184 during the 5 weeks incubation (data not shown). Although no replicate analysis was 185 performed for organic carbon and nitrogen content, the carbon content tended to be lower in 186 oxidized than control soil, while nitrogen content was not affected. After Fenton H treatment, 187 several parameters were strongly affected: a CEC decrease of 2 units, a pH decrease of 2.5 188 units and a decrease of available phosphorus ( $77 \%$ of the initial content) were measured. 
191 No production of $\mathrm{CO}_{2}$ was observed in the abiotic controls (data not shown). The Fenton $\mathrm{H}$ treatment significantly and rapidly increased carbon mineralization rate, while mineralization

193 rate was not significantly different with Fenton L treated and control soil (Figure 1). After 194 oxidation (T0), the number of culturable heterotrophs, the 16S, 18S rDNA and PAH 195 degrading $\left(\mathrm{PAH}_{-\mathrm{RHD}}\right)$ gene copy numbers were significantly lower in Fenton $\mathrm{H}$ treated than 196 in control soil (Figure 2). After 5 weeks of incubation (T5), these numbers were significantly 197 higher than at T0 in Fenton $\mathrm{H}$ treated soil (Figure 2), while they did not significantly differ 198 between T0 and T5 for control and Fenton L treated soils. After 5 weeks the number of 199 culturable heterotrophs and of $18 \mathrm{~S}$ rDNA gene copies were even significantly higher in 200 Fenton $\mathrm{H}$ treated than in control soil. However, in Fenton $\mathrm{L}$ treated soil there was no 201 significant difference in culturable heterotrophs, 16S, 18S and PAH-RHD gene copy number 202 with the control soil at T0 and five weeks after incubation (T5).

\subsection{Effect of treatment on germination and growth}

205 Ryegrass germination rate reached $75-80 \%$ in Fenton treated and control soil after 14 days. 206 However, a 3-days significant delay in seed germination was observed for the Fenton $\mathrm{H}$ 207 treated soil (Figure 3). Root and shoot biomass was significantly lower in Fenton H treated 208 soil (35\% and $43 \%$ decrease) than in the control soil, but it was not affected in Fenton L 209 treated soil (Figure 4).

\section{Discussion}


214 The modified Fenton reaction applied in unsaturated conditions significantly reduced the 215 amount of PAHs in soil. The degradation concerned the different PAHs except the lower 216 molecular weight ones. Similar degradation rates of PAHs regardless of the number of 217 aromatic rings or lower degradation rates of higher molecular weight PAHs were previously 218 reported depending on the $\mathrm{H}_{2} \mathrm{O}_{2} / \mathrm{Fe}^{2+}$ ratio (Tran et al., 2010). However, our degradation rate, 219 obtained with 5-56 g oxidant added for $1 \mathrm{~g}$ PAHs, was lower than observed in other studies where higher concentrations of oxidants were applied in saturated conditions (100 to $4000 \mathrm{~g}$ oxidant for $1 \mathrm{~g}$ PAHs) for spiked (Nam et al., 2001; Kulik et al., 2006) or aged contaminated soils (Nam et al., 2001; Jonsson et al., 2006, 2007). In soil, the non specific action of hydroxyl radicals could oxidize the targeted molecules as well as the organic matter, which increases the quantity of oxidant needed to degrade PAHs. The soil contains more than $50 \mathrm{~g} \mathrm{~kg}^{-1}$ of organic carbon and PAHs represent only 2\% of it (Monsérié et al., 2009). The apparent lower $\mathrm{C}_{\text {org }}$ content in both oxidized treatments than in the control soil, could be due to the action of hydroxyl radicals, but this should be confirmed by further investigations. Moreover, the soil used in this study had a high carbonate content which can limit the efficiency of Fenton reaction. At the same time, this reaction lead to a decrease of $\mathrm{pH}$, probably due to the 230 injection of an acidic $\mathrm{H}_{2} \mathrm{O}_{2}$ solution and to the reaction between Fe (III) and $\mathrm{H}_{2} \mathrm{O}_{2}$ (Huling and 231 Pivetz, 2006). Carbonates can also buffer the environment of hydroxyl radicals which present 232 a higher efficiency in acidic conditions (Huling and Pivetz, 2006). Another explanation could 233 be the low accessibility of aged pollutants in this historically contaminated soil (Katayama et 234 al., 2010; Ouvrard et al., 2011). Contrary to other studies, the contact between PAHs and the 235 reagent was not enhanced by the use of a high volume of solution. The fact that hydroxyl radicals have a short half life (Sies, 1993) added to the difficulty to access PAHs located in 237 newly formed aggregates specific to the industrial soil (Monsérié et al., 2009) can be another 238 limitation for the degradation by such chemical processes. 
Soil fertility was affected by the Fenton oxidation with the higher concentration of oxidant 240 added. The main effect was a decrease of soil $\mathrm{pH}$, a negative effect on plant growth, as 241 previously observed by Sirguey et al. (2008) and a decrease of CEC and available P. The 242 decrease in CEC could be explained by the consequence of the $\mathrm{pH}$ drop on the charge of the 243 organic matter carboxyl groups, which partly turned to $\mathrm{COOH}$ instead of $\mathrm{COO}^{-}$(Sirguey et 244 al., 2008). Moreover, it can result from the ionisation in acidic conditions of mineral $\mathrm{OH}$ 245 groups. Cation exchange capacity reflects the mobility and the availability of ions which are important components of soil fertility. The decrease of available phosphorus content could result from the formation of ferric phosphate in acid condition which is an insoluble form of 248 phosphorus. The $\mathrm{pH}$ decrease, the low available phosphorus content and the decrease of 249 cation exchange capacity could explain the decrease of biomass and root elongation. Soil 250 fertility and plant growth could possibly be restored by addition of ameliorants (lime, fertilizer) (Séré et al., 2008).

252 Besides decreasing soil fertility, the oxidation treatment affected microbial density and 253 activity. The decrease in bacterial, fungal, and PAH degrading bacteria population densities 254 could be explained by the toxicity of hydroxyl radicals strongly reacting with biological 255 membranes (Slater, 1984). Moreover, the heat produced by the exothermic Fenton reaction 256 and the decrease of $\mathrm{pH}$ could contribute to the decreased microbial number and activity just 257 after chemical oxidation. The decrease of the number of microorganisms after Fenton reaction 258 as well as the rebound have been previously observed (Ferguson et al., 2004; Palmroth et al., 259 2006b; Sahl and Munakata-Marr, 2006). The increased microbial activity, estimated by the 260 increased $\mathrm{CO}_{2}$ release, and the increased number of cultivable and total bacteria and fungi 261 during incubation after oxidation indicated that recolonization occurred. Cultivable bacteria 262 which are heterotrophic preferentially use the most available organic carbon. The dead 263 bacterial cells (Palmroth et al., 2006b) as well as the organic carbon affected by the oxidation 
treatment (Leifeld and Kögel-Knabner, 2001; Mikutta et al., 2005) could potentially provide a 265 supplementary available amount of organic carbon. Contrary to other studies, no further degradation of PAHs occurred in our experiment following oxidation, and no variations in PAH-degrading populations were observed. However, it was previously shown that PAH availability in this historically contaminated soil was low and limited natural attenuation

269 (Ouvrard et al. 2011).

\section{Conclusion}

272 Partial removal of PAHs (14 and 22\%) in a historically contaminated soil was possible in 273 unsaturated conditions using Fenton reagents with the low and high doses of $\mathrm{H}_{2} \mathrm{O}_{2}(6$ and $65 \mathrm{~g}$

$\left.274 \mathrm{~kg}^{-1}\right)$. The impact of chemical oxidation on PAH concentration and soil physico-chemical and 275 biological parameters differed with the level of reagent used. PAH degradation was not 276 proportional to the quantity of reagent added. With the highest oxidant level applied, soil 277 parameters were highly impacted, especially $\mathrm{pH}$ value and biological parameters such as the 278 quantity of microorganisms, seed germination and plant growth. The impact on 279 microbiological parameters was temporary and disappeared rapidly. Specific microbial 280 functions could be investigated to further check whether soil microbial functioning was 281 affected. Reduction of soil $\mathrm{pH}$ was a major limiting factor for plant growth at high level of 282 oxidant. Further investigations could be performed with different concentrations of reagents 283 to optimize PAH degradation without impact on vegetation. Otherwise, chemical oxidation 284 could be combined with soil restoration strategies.

\section{Acknowledgments}


288 This work was funded by the ANR-Precodd Oxysol project, the French Government and the 289 Lorraine Region (GISFI project, www.gisfi.fr). The authors thank Prof. Marie-Odile 290 Simonnot and Jean-Christophe Renat (Valterra Company) for fruitful discussions and advices.

\section{References}

295 Biache, C., Mansuy-Huault, L., Faure, P., Munier-Lamy, C., Leyval, C., 2008. Effects of 296 thermal desorption on the composition of two coking plant soils: Impact on solvent 297 extractable organic compounds and metal bioavailability. Environ. Poll. 156, 671-677.

298 Binet, P., Portal, J.M., Leyval, C., 2000. Dissipation of 3-6-ring polycyclic aromatic 299 hydrocarbons in the rhizosphere of ryegrass. Soil Biol. Biochem. 32, 2011-2017.

300 Bispo, A., Jourdain, M.J., Jauzein, M., 1999. Toxicity and genotoxicity of industrial soils 301 polluted by polycyclic aromatic hydrocarbons (PAHs). Org. Geochem. 30, 947-952.

302 Cajthaml, T., Bhatt, M., Šašek, V., Matějů, V., 2002. Bioremediation of PAH-contaminated 303 soil by composting: A case study. Folia Microbiol. 47, 696-700.

304 Cébron, A., Norini, M.-P., Beguiristain, T., Leyval, C., 2008. Real-Time PCR quantification 305 of PAH-ring hydroxylating dioxygenase (PAH-RHD[alpha]) genes from Gram positive and

306 Gram negative bacteria in soil and sediment samples. J. Microbiol. Methods. 73, 148-159.

307 Felske, A., Akkermans, A.D.L., De Vos, W.M., 1998. Quantification of 16S rRNAs in 308 complex bacterial communities by multiple competitive reverse transcription-PCR in 309 temperature gradient gel electrophoresis fingerprints. Appl. Environ. Microbiol. 64, 4581$310 \quad 4587$. 
311 Ferguson, S.H., Woinarski, A.Z., Snape, I., Morris, C.E., Revill, A.T., 2004. A field trial of in

312 situ chemical oxidation to remediate long-term diesel contaminated Antarctic soil. Cold 313 Regions Sci. Tech. 40, 47-60.

314 Fismes, J., Schwartz, C., Perrin-Ganier, C., Morel, J.-L., Charissou, A.-M., Jourdain, 2004.

315 Risk of contamination for edible vegetables growing on soiols polluted by polycyclic 316 aromatic hydrocarbon. Polycyclic Aromat. Compd. 24, 827-836.

317 Gan, S., Lau, E.V., Ng, H.K., 2009. Remediation of soils contaminated with polycyclic 318 aromatic hydrocarbons (PAHs). J. Hazard. Mater. 172, 532-549.

319 Huling, S.G., Pivetz, B.E., 2006. In-Situ Chemical Oxidation - Engineering Issue. 320 (EPA/600/R-06/072), pp. 1-60.

321 Jonsson, S., Persson, Y., Frankki, S., Lundstedt, S., Bavel, B.v., Haglund, P., Tysklind, M., 322 2006. Comparison of Fenton's reagent and ozone oxidation of polycyclic aromatic

323 hydrocarbons in aged contaminated soils. J. Soil. Sediment. 6, 208-214.

324 Jonsson, S., Persson, Y., Frankki, S., van Bavel, B., Lundstedt, S., Haglund, P., Tysklind, M., 325 2007. Degradation of polycyclic aromatic hydrocarbons (PAHs) in contaminated soils by 326 Fenton's reagent: A multivariate evaluation of the importance of soil characteristics and PAH 327 properties. J. Hazard. Mater. 149, 86-96.

328 Katayama, A., Bhula, R., Burns, G.R., Carazo, E., Felsot, A., Hamilton, D., Harris, C., Kim, 329 Y.-H., Kleter, G., Koerdel, W., Linders, J., Peijnenburg, J.G.M.W., Sabljic, A., Stephenson, 330 R.G., Racke, D.K., Rubin, B., Tanaka, K., Unsworth, J., Wauchope, R.D., 2010. 331 Bioavailability of xenobiotics in the soil environment. Rev. Environ. Contam. T. 203, 1-86.

332 Kulik, N., Goi, A., Trapido, M., Tuhkanen, T., 2006. Degradation of polycyclic aromatic 333 hydrocarbons by combined chemical pre-oxidation and bioremediation in creosote 334 contaminated soil. J. Environ. Manage. 78, 382-391. 
Lee, B.-D., Hosomi, M., 2001. A hybrid Fenton oxidation-microbial treatment for soil highly contaminated with benz(a)anthracene. Chemosphere 43, 1127-1132.

Leifeld, J., Kögel-Knabner, I., 2001. Organic carbon and nitrogen in fine soil fractions after treatment with hydrogen peroxide. Soil. Biol. Biochem. 33, 2155-2158.

Lueders, T., Wagner, B., Claus, P., Friedrich, M.W., 2004. Stable isotope probing of rRNA 340 and DNA reveals a dynamic methylotroph community and trophic interactions with fungi and 341 protozoa in oxic rice field soil. Environ. Microbiol. 6, 60-72.

342 Maxim, L., Spangenberg, J.H., 2009. Driving forces of chemical risks for the European 343 biodiversity. Ecolog. Econ. 69, 43-54.

344 Mikutta, R., Kleber, M., Kaiser, K., Jahn, R., 2005. Review: organic matter removal from 345 soils using hydrogen peroxide, sodium hypochlorite, and disodium peroxodisulfate. Soil Sci. 346 Soc. Am. J. pp. 120-135.

347 Monsérié, M.-F., Watteau, F., Villemin, G., Ouvrard, S., Morel, J.-L., 2009. Technosol 348 genesis: identification of organo-mineral associations in a young Technosol derived from 349 coking plant waste materials. J. Soil. Sediment. 9, 537-546.

350 Nam, K., Rodriguez, W., Kukor, J.J., 2001. Enhanced degradation of polycyclic aromatic 351 hydrocarbons by biodegradation combined with a modified Fenton reaction. Chemosphere 45, $352 \quad 11-20$.

353 Ouvrard S., Barnier C., Bauda P., Beguiristain T., Biache C., Bonnard M., Caupert C., Cébron 354 A., Cortet J., Cotelle S., Dazy M., Faure P., Masfaraud J. F., Nahmani J., Palais F., Poupin P., 355 Raoult N., Vasseur P., Morel J.L., Leyval C., 2011. In situ assessment of phytotechnologies 356 for multicontaminated soil management. Int. J. Phytoremediat. , 13:sup1, 245-263.

357 Palmroth, M., Langwaldt, J., Aunola, T., Goi, A., Puhakka, J., Tuhkanen, T., $2006 a$. 358 Treatment of PAH-contaminated soil by combination of Fenton's reaction and biodegradation.

359 J. Chem. Technol. Biotechnol. 81, 598-607. 
360 Palmroth, M., Langwaldt, J., Aunola, T., Goi, A., Münster, U., Puhakka, J., Tuhkanen, T., 361 2006b. Effect of modified Fenton's reaction on microbial activity and removal of PAHs in 362 creosote oil contaminated soil. Biodegradation 17, 29-39.

363 Quantin, C., Joner, E.J., Portal, J.M., Berthelin, J., 2005. PAH dissipation in a contaminated 364 river sediment under oxic and anoxic conditions. Environ. Poll. 134, 315-322.

365 Rivas, F.J., 2006. Polycyclic aromatic hydrocarbons sorbed on soils: A short review of 366 chemical oxidation based treatments. J. Hazard. Mater. 138, 234-251.

367 Sahl, J., Munakata-Marr, J., 2006. The effects of in situ chemical oxidation on 368 microbiological processes: A review. Remed. J. 16, 57-70.

369 Séré, G., Schwartz, C., Ouvrard, S., Sauvage, C., Renat, J.-C., Morel, J., 2008. Soil 370 construction: A step for ecological reclamation of derelict lands. J. Soil. Sediment. 8, 130371136.

372 Sies, H., 1993. Strategies of antioxidant defense. Eur. J. Biochem. 215, 213-219.

373 Sirguey, C., De Souza e Silva, P.T., Schwartz, C., Simonnot, M.-O., 2008. Impact of chemical 374 oxidation on soil quality. Chemosphere 72, 282-289.

375 Slater, T.F., 1984. Free-radical mechanisms in tissue injury. Biochem. J. 222, 1-15.

376 Smith, M.J., Flowers, T.H., Duncan, H.J., Alder, J., 2006. Effects of polycyclic aromatic 377 hydrocarbons on germination and subsequent growth of grasses and legumes in freshly 378 contaminated soil and soil with aged PAHs residues. Environ. Poll. 141, 519-525.

379 Sun, H.-W., Yan, Q.-S., 2008. Influence of pyrene combination state in soils on its treatment 380 efficiency by Fenton oxidation. J. Environ. Manage. 88, 556-563.

381 Tran, L.-H., Drogui, P., Mercier, G., Blais, J.-F., 2010. Comparison between Fenton oxidation 382 process and electrochemical oxidation for PAH removal from an amphoteric surfactant 383 solution. J. Appl. Electrochem. 40, 1493-1510. 
385 Valderrama, C., Alessandri, R., Aunola, T., Cortina, J.L., Gamisans, X., Tuhkanen, T., 2009.

386 Oxidation by Fenton's reagent combined with biological treatment applied to a creosote387 comtaminated soil. J. Hazard. Mater. 166, 594-602.

388 Wang, X., Yu, X., Bartha, R., 1990. Effect of bioremediation on polycyclic aromatic 389 hydrocarbon residues in soil. Environ. Sci. Technol. 24, 1086-1089.

390 Westerhoff, P., Aiken, G., Amy, G., Debroux, J., 1999. Relationships between the structure of 391 natural organic matter and its reactivity towards molecular ozone and hydroxyl radicals.

392 Water Res. 33, 2265-2276.

393 White, P.A., Claxton, L.D., 2004. Mutagens in contaminated soil: a review. Mutat. Res., Rev.

394 Mutat. Res. 567, 227-345.

395

396

397

398

399

400

401

402

403

404

405

406

407

408

409 
412 Figure 1: Cumulated production of $\mathrm{CO}_{2}$ over time of incubation with oxidized (Fenton $\mathrm{L}$ and

$413 \mathrm{H})$ and control soil (Control). Mean $\pm \mathrm{SE}(\mathrm{n}=5)$. Arrows represent days of oxigenation.

414

415 Figure 2: Density of cultivable bacteria, 16S rDNA, PAH-RDH $\alpha$ and 18s rDNA gene copy

416 numbers in oxidized (Fenton $\mathrm{L}$ and $\mathrm{H}$ ) and control soil (Control) at the start (T0) and after 5

417 weeks (T5) of incubation. As the evolution of PAH-RHD $\mathrm{P}_{\alpha} \mathrm{GN}$ and GP populations was not

418 significantly different, the two populations were added to represent the global population of

419 degraders. Mean \pm SE $(n=3)$. LD: detection limit. Different letters within category data

420 indicate significant differences between treatments; stars indicate significant differences

421 between $\mathrm{T}_{0}$ and $\mathrm{T}_{6}$ by Mann and Whitney test.

422

423 Figure 3: Germination rate (\%) of Lolium perenne seeds in oxidized (Fenton L and $\mathrm{H}$ ) and

424 control soil. Mean $\pm \mathrm{SD}(\mathrm{n}=5)$. Stars indicate a significant difference between Fenton $\mathrm{H}$

425 treated and Control soil

426

427 Figure 4: Shoot and root dry weight of Lolium perenne after 4 weeks on oxidized (Fenton L 428 and $\mathrm{H}$ ) and control soil. (Mean \pm SE. $\mathrm{n}=5$ ). Values followed by the same letter are not 429 significantly different at the 5\% level (two-way ANOVA, Tukey test) 
440 Table 1: Physico-chemical characteristics of the soil after Fenton treatment at low (L) and 441 high $(\mathrm{H})$ concentration of oxidant. Concentrations of PAHs, given as mean, followed by the 442 same letter are not significantly different at the 5\% level (one-way ANOVA, Tukey test)

443

\begin{tabular}{|c|c|c|c|c|}
\hline & & Control & Fenton $\mathrm{L}$ & Fenton $\mathrm{H}$ \\
\hline & Units & & & \\
\hline Org C & $\left(g k g^{-1}\right)$ & 61,7 & 57.7 & 57.1 \\
\hline $\mathbf{N}$ & $\left(g \mathrm{~kg}^{-1}\right)$ & 2.4 & 2.4 & 2.3 \\
\hline Olsen P & $\left(g \mathrm{~kg}^{-1}\right)$ & 0.049 & 0.068 & 0.011 \\
\hline CEC & $\left(\mathrm{cmol} \mathrm{kg}^{-1}\right)$ & 10.3 & 10.5 & 8.7 \\
\hline pH & & 7.3 & 7.4 & 4.9 \\
\hline Naphthalene & & $24.8^{\mathrm{a}}$ & $26.4^{\mathrm{a}}$ & $22.0^{\mathrm{a}}$ \\
\hline Acenapthtylene & & $0.7^{\mathrm{a}}$ & $0.6^{\mathrm{a}}$ & $0.8^{\mathrm{a}}$ \\
\hline Acenaphthene & & $57.9^{\mathrm{a}}$ & $54.8^{\mathrm{a}}$ & $52.7^{\mathrm{a}}$ \\
\hline Fluorene & & $25.9^{\mathrm{a}}$ & $22.9^{\mathrm{b}}$ & $20.4^{\mathrm{b}}$ \\
\hline Phenanthrene & & $89.1^{\mathrm{a}}$ & $80.9^{\mathrm{ab}}$ & $72.9^{b}$ \\
\hline Anthracene & & $36.8^{\mathrm{a}}$ & $26.2^{\mathrm{b}}$ & $23.6^{\mathrm{b}}$ \\
\hline Fluoranthene & & $235.5^{\mathrm{a}}$ & $206.1^{\mathrm{b}}$ & $186.9^{\mathrm{c}}$ \\
\hline Pyrene & & $128.8^{\mathrm{a}}$ & $111.4^{\mathrm{b}}$ & $102.6^{\mathrm{c}}$ \\
\hline Benzo(a)Anthracene & $\left(\mu g k g^{-1}\right)$ & $101.2^{\mathrm{a}}$ & $87.0^{\mathrm{b}}$ & $78.4^{\mathrm{c}}$ \\
\hline Chrysene & & $56.7^{\mathrm{a}}$ & $47.4^{\mathrm{b}}$ & $42.9^{\mathrm{c}}$ \\
\hline Benzo(b)Fluoranthene & & $96.7^{\mathrm{a}}$ & $83.5^{\mathrm{b}}$ & $77.3^{\mathrm{b}}$ \\
\hline Benzo(k)Fluoranthene & & $30.8^{\mathrm{a}}$ & $26.6^{\mathrm{b}}$ & $24.5^{\mathrm{b}}$ \\
\hline Benzo(a)Pyrene & & $108.8^{\mathrm{a}}$ & $91.5^{\mathrm{b}}$ & $84.7^{\mathrm{b}}$ \\
\hline Dibenzo(a.h)Anthracene & & $13.1^{\mathrm{a}}$ & $11.3^{\mathrm{b}}$ & $11.0^{\mathrm{b}}$ \\
\hline Benzo(g.h.i)Perylene & & $64.2^{\mathrm{a}}$ & $52.7^{\mathrm{b}}$ & $48.4^{\mathrm{b}}$ \\
\hline Indeno(1.2.3-cd)Pyrene & & $90.9^{\mathrm{a}}$ & $75.4^{\mathrm{b}}$ & $68.8^{\mathrm{b}}$ \\
\hline Total PAHs & & $1161.9^{\mathrm{a}}$ & $1004.9^{\mathrm{b}}$ & $917.9^{c}$ \\
\hline
\end{tabular}




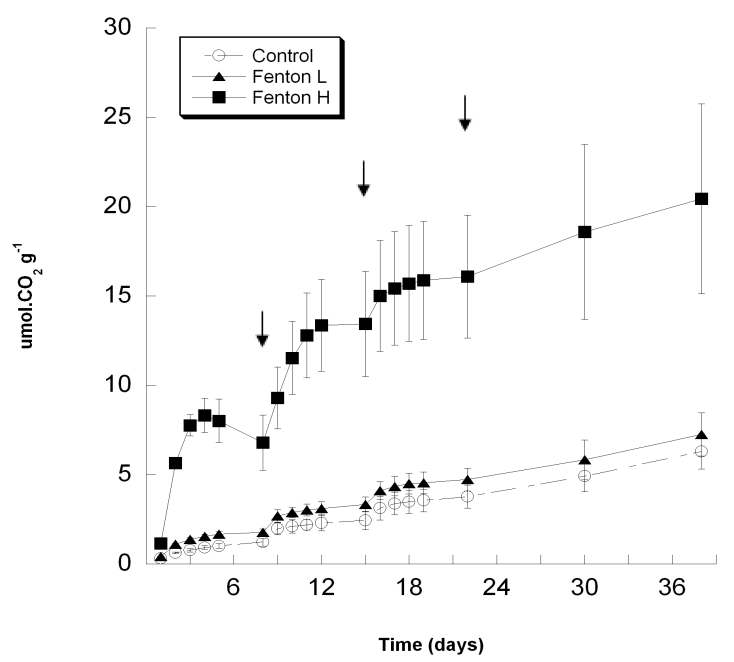

457 Figure 1

458

459

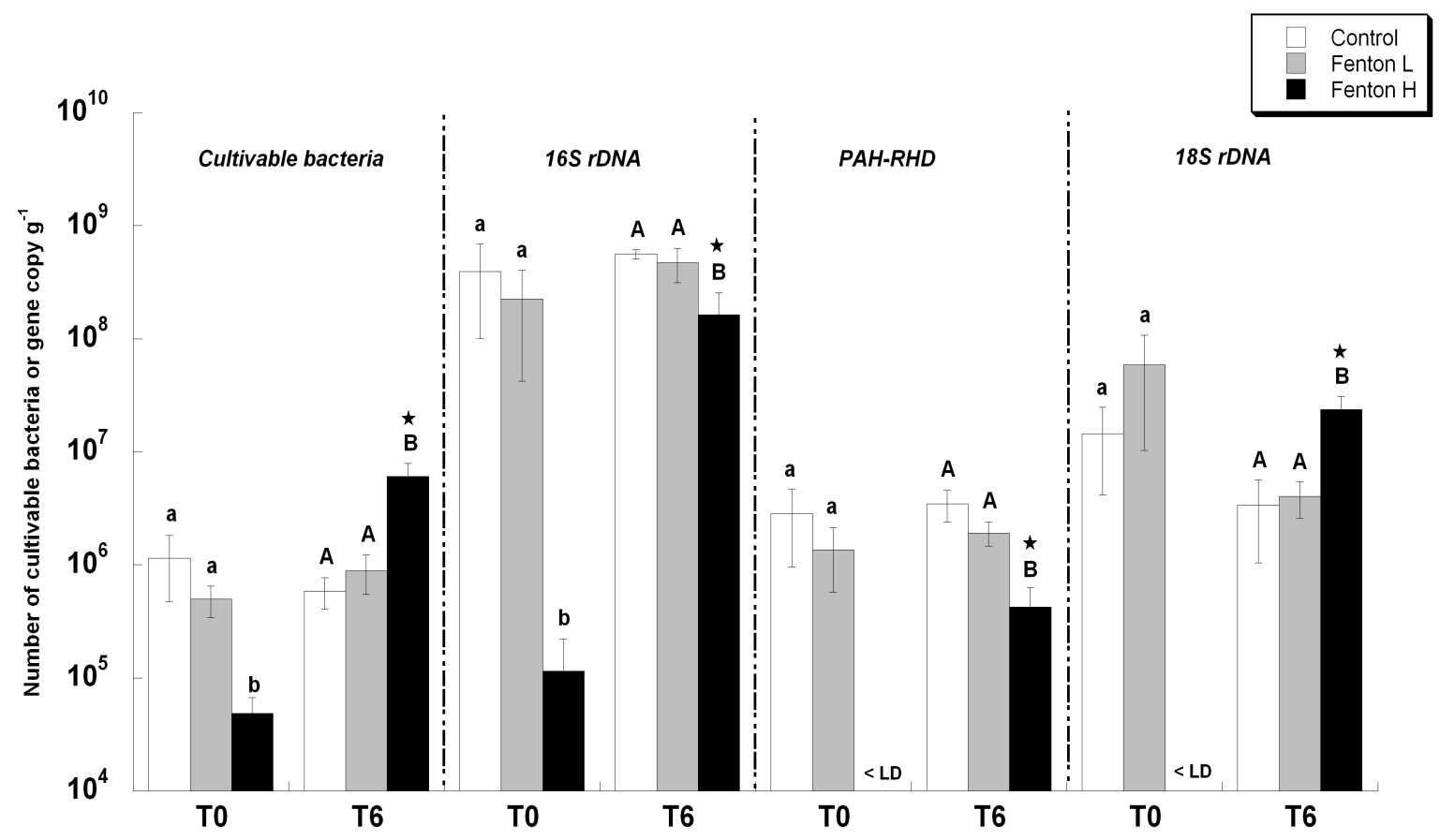

460 Figure 2

461 
